\title{
DESCRIPTION OF GADGET ADDICTION, SLEEP QUALITY, AND STUDENTS LEARNING ACHIEVEMENT AT SD NEGERI 1 SIDODADI LAWANG IN 2019
}

Dimas Cahyo Wibowo ${ }^{1}$, Della Wahyu Fitriani $^{1}$, Ananda Febina Kimresti ${ }^{1}$, Alfan Ahkami $^{1}$, Isna Sandria Nastiti ${ }^{1}$, Syarifah Dwi Auliani ${ }^{1}$, Siti Ermawati ${ }^{1}$, Sabrina Rizki Andriani $^{1}$, Sulistiawati ${ }^{2}$ iD, Priyo Raharjo ${ }^{3}$

${ }^{1}$ Faculty of Medicine, Universitas Airlangga, Indonesia ${ }^{2}$ Department Public Health-Preventive Medicine, Faculty of Medicine, Universitas Airlangga, Indonesia ${ }^{3}$ UPT Latkesmas Murnajati, Lawang, Malang, Indonesia

\section{ABSTRACT}

In this globalization era, technology is increasing rapidly. One of the technologies is a gadget/device. Gadget users come from various backgrounds, ranging from adults, the elderly, and even children. The Daily Mail reports that $70 \%$ of elementary schoolaged children can easily use a gadget. The use of gadgets can have both positive and negative effects on children. The negative effect of using a gadget is affecting the quality of sleep and learning achievement on children. The study aimed to describe gadget addiction, sleep quality, and learning achievement of children focused on grades 5th and 6th at SD Negeri 1 Sidodadi Lawang. A descriptive study method. The total population of grade 5th and 6th students at SD Negeri 1 Sidodadi Lawang are 96 students. Data were taken by using Smart Addiction Scale, Pittsburgh Sleep Quality Index questionnaires, and students' report cards. The distribution of gadget addiction levels in this study was 21 people $(21,9 \%)$ with a low level, 72 people (75\%) with a moderate level, and 3 people $(3,1 \%)$ with a high level. There were 73 people $(76 \%)$ with poor sleep quality and 49 people (51\%) with poor learning achievement. The level of gadget addiction in 5th and 6th-grade students at SD Negeri 1 Sidodadi Lawang was dominant in the medium level, sleep quality was dominant in the poor level.

\section{ARTICLE HISTORY}

Received: June 20, 2021 Revised: July 20, 2020

Accepted: August 10, 2020

Published: August 30, 2020

(Online)

doi

10.20473/jcmphr.v1i2.21698

\section{KEYWORDS}

gadget addiction, sleep quality, learning achievements

\section{CORRESPONDING}

AUTHOR

Sulistiawati

凹sulistiawati@fk.unair.ac.id

Department of Public Health-

Preventive Medicine, Faculty

of Medicine, Universitas

Airlangga, Surabaya, Indonesia

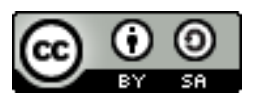

\section{INTRODUCTION}

In the current era of globalization, technological advances are increasing rapidly. Technology companies compete in increasing the sophistication of their application features to consumers. Technology is very easy to find even in rural areas because of the low price with adequate quality. Technology is developing very rapidly today, one of which is gadgets. The gadget is an English term that defines a small electronic gadget with various functions, according to Osland. Gadgets can be computers, smartphones, and tablet PCs. Gadgets are currently in trend and have even become a necessity for most people. $^{1}$

Gadget users come from all walks of life, including adults, the elderly, and even children. Usually, the gadget used most often is a smartphone. Smartphones today are no longer a luxury item so the need for smartphones is getting higher. It is predicted that smartphone customer turnover in Indonesia will reach $8.6 \%$ in a month. The digital marketing research 
institute Emarketer estimates that in 2018 the number of active smartphone users in Indonesia will be more than 100 million people. According to KOMINFO in 2018 with such a large number, Indonesia will become the country with the fourth largest active smartphone user in the world after China, India, and America. In 2013, the Daily Mail reported that $29 \%$ of children at an early age could easily use their gadgets and $70 \%$ of them were elementary schoolaged children. The United States Centers for Disease Control and Prevention states that the average child spends about 8 hours a day watching electronic screens. According to Sundus 2018, children use gadgets to play games, watch videos/movies, listen to music, chat with friends, and browse websites. They usually spend time with these activities regardless of posture position, screen brightness, and distance from the screen to the eyes, which greatly affect the health and acuity of their eyes. $^{2,3}$

Sleep is a complex process in which our bodies perform several important activities. One of the necessities that everyone needs is sleep. Sleep is a complex physiological process that is regulated globally, regionally, and locally by cellular and molecular mechanisms. Another definition, Sleep is a naturally recurring state of mind and body, characterized by altered consciousness, relatively inhibited sensory activity, reduced muscle activity, and inhibition of nearly all voluntary muscles during rapid eye movement (REM) sleep, and reduced interaction with the environment. Sleep is one mechanism to restore the brain. sleep also helps the brain to recover and regenerate. During our sleep, the brain can process information, consolidate memories, and enable us to learn and function effectively during the day. ${ }^{4,5}$

According to the Kamus Besar Bahasa Indonesia, learning achievement is the mastery of knowledge or skills developed by subjects, usually shown by the test scores or the scores given by the teacher. Meanwhile, according to Winkel (1986), learning achievement is one proof that shows the ability or success of a person who carries out the learning process according to the weight or value he has achieved. The learning activity is a process, while learning achievement is the result of the learning process. Learning achievement is said to be satisfactory if it can fulfill three aspects, namely: cognitive (knowledge), affective (attitude), and psychomotor (skills), on the other hand, it is said that achievement is not satisfactory if an individual has not been able to meet the three criteria. ${ }^{6}$

\section{MATERIALS AND METHODS}

This research used a descriptive type, conducted at SD Negeri 1 Sidodadi, Sidodadi Village, Krajan Hamlet, Lawang District, Malang Regency, from 9 to 14 December 2019. The population in this study were all school children grade 5 th and 6th at SD Negeri 1 Sidodadi. Krajan Hamlet, Sidodadi Village, Lawang District, Malang Regency in 2019, totaling 94 children. The sample in this study used a total sampling technique with the criteria of all students using gadgets and filling out the questionnaire completely. 
The instrument in this study used a smartphone addiction questionnaire using a Likert scale, a PSQI (The Pittsburgh Sleep Quality Index) questionnaire, and the report card/exam scores of SD Negeri 1 Sidodadi Lawang children. The variables used in this study were general characteristics, gadget addiction, sleep quality, and learning achievement.

Field preparation in this research begins with obtaining a permit from the IKM-KP section of the Faculty of Medicine, Airlangga University, then proceed with processing a permit to Bakesbangpol Malang Regency. The research was carried out by obtaining a permit to the Sidodadi village office and the Principal of SD Negeri Sidodadi 1 Lawang. This research ethic has also passed ethics from the Ethics Commission of the Faculty of Medicine, Universitas Airlangga. This study has used primary data collected from the results of filling out questionnaires by children in grades 5th and 6th at SD Negeri Sidodadi 1 Lawang about gadget addiction on sleep quality and children's learning achievement at school.

\section{RESULTS}

Table 1. Distribution of Respondent Demographic Characteristics

\begin{tabular}{|c|c|c|c|c|}
\hline No & Demographic Characteristics & Category & Total & $\%$ \\
\hline \multirow{2}{*}{1} & \multirow{2}{*}{ 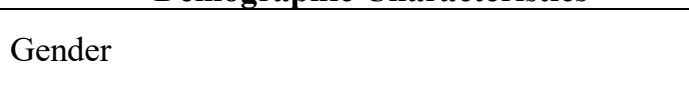 } & Male & 54 & 56.3 \\
\hline & & Female & 42 & 43.8 \\
\hline \multirow{2}{*}{2} & \multirow{2}{*}{ Gadgets ownership } & Belong to parents & 29 & 30.2 \\
\hline & & One's own & 67 & 69.8 \\
\hline \multirow{2}{*}{3} & \multirow{2}{*}{ Parents care when children play gadgets } & Yes & 76 & 79.2 \\
\hline & & No & 20 & 20.8 \\
\hline \multirow{2}{*}{4} & \multirow{2}{*}{ Parental supervision when playing gadgets } & Yes & 45 & 46.9 \\
\hline & & No & 51 & 53.1 \\
\hline \multirow{2}{*}{5} & \multirow{2}{*}{ The punishment for playing gadgets for too long } & Yes & 64 & 66.7 \\
\hline & & No & 32 & 33.3 \\
\hline \multirow{2}{*}{6} & \multirow{3}{*}{ Parents often play gadgets } & Yes & 64 & 66.7 \\
\hline & & No & 32 & 33.3 \\
\hline 7 & & Yes & 11 & 11.5 \\
\hline
\end{tabular}




\begin{tabular}{llccc} 
& $\begin{array}{l}\text { Parents are busy playing gadgets so they pay less } \\
\text { attention to their children }\end{array}$ & No & 85 & 88.5 \\
8 & Parents care if children use gadgets for too long & Yes & 76 & 79.2 \\
& No & 20 & 20.8 \\
\hline TOTAL & & 126 & 100 \\
\hline
\end{tabular}

Based on table 1, it shows that this study was dominated by the male as many as 54 people $(56.3 \%)$. The majority of respondents already have their own gadgets, as many as 67 people $(69.8 \%)$. As many as 76 people $(79.2 \%)$ of parents who care about their mobile gadgets. Most of the respondents got sanctions if they played the gadget too long as many as 64 people (66.7\%). The number of parents who play gadgets according to respondents is 68 people $(70.8 \%)$, only 11 parents $(11.5 \%)$ were busy playing gadgets so they didn't care about the respondent.

Table 2. Level of Gadgets Addiction, Sleep Quality, and Learning Achievement of 5th-6th Grade at SD Negeri 1 Sidodadi Lawang

\begin{tabular}{ccccc}
\hline No & Variable & Level & $\mathbf{N}$ & $\mathbf{\%}$ \\
\hline \multirow{2}{*}{1} & \multirow{2}{*}{ Gadget addiction } & Low & 21 & 21.9 \\
& & Moderate & 72 & 75 \\
2 & \multirow{3}{*}{ Sleep quality } & High & 3 & 3.1 \\
& & Good & 23 & 24 \\
3 & \multirow{3}{*}{ Learning Achievement } & Poor & 73 & 76 \\
& & Good & 47 & 49 \\
& TOTAL & Poor & 49 & 51 \\
\hline
\end{tabular}

Based on table 2, it shows that the variables studied had respondents with a low level of gadget dependency as many as 21 people $(21.9 \%)$, moderate as many as 72 people $(75.0 \%)$, and high as many as 3 people $(3.1 \%)$. Then the quality of sleep has respondents with a good level of 23 people (24.0\%), and learning achievement has respondents with a bad level of 49 people $(51.0 \%)$.

\section{DISCUSSION}

Based on the results of research from 96 respondent data, there were male respondents as many as 54 children $(56.3 \%)$ and female respondents as many as 42 children (43.8\%). The results of this study by the research of Badri, et al. (2017), namely the presentation of boys who often use gadgets as much as $85.83 \%$ of the total sample. This can be due to several factors, including interest in online games, searching for electronic stores, and simply looking at internet pages. ${ }^{7,8}$

There were 67 students of SD Negeri 1 Sidodadi Lawang who have their gadgets (69.8) and 29 children (30.2\%) who use gadgets owned by their parents. This research is in line with research conducted by Nikmah (2013) which states that $99 \%$ of children in the total sample of his study have personal gadgets and this is not in line with the article from The Asian Parents Insight in 2014 which stated that $67 \%$ of children in Southeast Asia. who use the gadget owned by his parents. ${ }^{9,10}$ Irmayanti (2018) which states that most parents have a willingness to accompany their children when playing gadgets. ${ }^{11}$ 
In terms of supervision, data obtained shows that the number of parents who supervise their children playing gadgets is lower, namely 45 parents (46.9) compared to parents who do not supervise their children playing gadgets, namely 51 parents (53.1\%). In modern times, parents still don't supervise their children in playing gadgets, compared to education, crime, and drug use. Research by Nuredah (2016) states that statistically, the role of parents does not have a significant effect on the negative impact of cellphones on children. The negative impact of cellphones is not only influenced by parental supervision but many other factors that affect it, such as the school environment, social media, friends and so on. ${ }^{12,13}$

Most of the respondents got sanctions if they played the gadget too long as many as 64 people $(66.7 \%)$. This research is in line with Gunawan \& Muhabbatillah's research (2019) regarding the sanctions given to children if they use the internet more than the specified limit, especially Facebook social media in the form of hacking Facebook accounts. ${ }^{14}$

According to the respondents, 68 parents (70.8\%) play gadgets, only 11 parents $(11.5 \%)$ are busy playing gadgets so they don't care about the respondent. This research is in line with research conducted by Rahmawati (2019) that almost all 122 respondents $(100 \%)$, namely mothers use gadgets, with a maximum duration of 13 hours per day and an average duration of about 3 hours per day. Besides, Rahmawati (2019) also explains that most mothers still care for their children, as many as 79 people $(64.8 \%)$ even though the mother owns and uses a gadget. ${ }^{15}$

\section{Gadget Addiction}

Respondents with a low level of gadget addiction were 21 people $(21.9 \%)$, while the medium level was 72 people $(75.0 \%)$, and three people (3.1\%) high. This result is in line with research conducted on 6th-semester students of Aisyiyah University Yogyakarta by Subhan (2018) who said that 162 people $(88.04 \%)$ of students had a moderate level of gadget dependency. However, this study is not in line with the research conducted by Muflih (2017) on students of SMA Negeri 1 Kalasan Yogyakarta in May 2015 which stated that 112 respondents $(54.1 \%)$ had a low dependence on their gadgets. The results of the research conducted by Saifullah (2017) that the highest percentage was moderate gadget addiction as many as 36 children $(51.4 \%)$, followed by low-level gadget addiction as many as 34 children (48.6\%), and no children were in high-level gadget addiction $(0 \%) .{ }^{16-18}$

\section{Sleep Quality}

Respondents who had good sleep quality were 23 people $(24.0 \%)$, while 73 respondents $(76 \%)$ had bad sleep quality.

\section{Learning achievement}

Respondents with good learning achievement were found as many as 47 children (47\%), while learning achievement was obtained by 49 children (51\%). This study is in line with research conducted by Nikmah (2013) which states that $99 \%$ of children who are gadget dependent have bad sleep quality. ${ }^{9}$

\section{CONCLUSION}

Based on the results of the study, the level of gadget addiction on grade 5 and 6 SD Negeri 1 Sidodadi Lawang was the most dominant at a moderate level as much as $75 \%$, sleep 
quality was most dominant at a bad level as much as $76 \%$, and learning achievement level was the most dominant at a bad level as much as $51 \%$.

\section{ACKNOWLEDGEMENT}

Thanks to staff and employees at the Department Public Health-Preventive Medicine, Faculty of Medicine, Universitas Airlangga, Surabaya, and Latkesmas Murnajati, as well as all parties who have contributed assistance to researchers so that researchers can complete this article.

\section{REFERENCES}

1. Efendi, F. 2013. Pengaruh gadget terhadap perkembangan anak usia dini. Available

from: http://fuadefendi.in/2014/01/p engaruhgadget-terhadap-perkembangan.html. [Accessed 8 December 2019].

2. Chuzaimah dkk, 2010. Smartphone: Antara Kebutuhan dan E-Lifestyle. Seminar Nasional Informatika 2010 (semnas IF 2010) UPN "Veteran" Yogyakarta.

3. Kominfo. 2017. Survey penggunaan teknologi informasi dan komunikasi tahun 2017. Available from: https://balitbangsdm.kominfo.go.id/?mo $\mathrm{d}=$ publikasi\&a $=$ dl\&page $\mathrm{id}=360 \& \mathrm{cid}=$ 9\&dow nload id=187. [Accessed 9 December 2019].

4. Mental Health. 2011. Mental Health Awarness Week UK. Available from: https://www.mentalhealth.org.uk/sites/d efault/files/MHF-Sleep-Report2011.pdf . [Accessed on 9 Dec 2019].

5. Potter, P.A., \& Perry A.G. 2005. Buku Ajar Fundamental Keperawatan: konsep, proses dan praktik, (edisi 4 volume 2). Alih bahasa Komalasari, R. et-al. Jakarta: EGC.

6. Sari, MI. 2018. Pengaruh Penggunaan Gadget Terhadap Motivasi dan Hasil
Belajar Siswa Kelas V MI Thoriqotussa'adah Pujon Kabupaten Malang. Universitas Islam Negeri Maulana Malik

7. Badri, Masood., Nuaimi, Ali Al., Guang, Yang,. Rashedi, Asma Al. 2017. School performance, social networking effects, and learning ofschool children: Evidence of reciprocal relationships in Abu Dhabi. Telematics and Informatics 34, 1433-1444.

8. Unplagan, Karthiyayini., Balasubramaniam, Barathi., Premkumar, Thiwya., Chien, Joey Lim Chum., Rao, Annushia Sivaji., Rasit, Ratna Agustina Sibarani Ahmat. 2018. Impact of electronic gadgets on the life of children: A cross sectional study from Ipoh, Perak, Malaysia. Quest International Journal of Medical and Health Sciences 1(2), 30-34

9. Nikmah, Astin. 2013. Dampak Penggunaan Hand Phone Terhadap Prestasi Siswa. E-Jurnal Dinas Pendidikan Kota Surabaya, Volume 5

10. The Asian Parents Insight. 2014. Mobile Gadget Usage Among Young Kids: A Southeast Asia Study. Singapore: The Asian Parent.

11. Irmayanti, Y. 2018. Peran Orang Tua dalam Mendampingi Penggunaan Gawai pada Anak Usia Prasekolah. Surakarta: Universitas Muhammadiyah Surakarta.

12. Kurnia, N., et al. 2019. Literasi Digital Keluarga Teori dan Praktik Pendampingan Orang Tua terhadap Anak dalam Berinternet. Yogyakarta : Gajah Mada University Press.

13. Nuredah, 2016. Peran Orangtua dalam Penanggulangan Dampak Negatif Handphone pada Anak Studi di SMPN 5 Yogyakarta. Universitas Islam Negeri Sunan Kalijaga Yogyakarta.

14. Gunawan, T. \& Muhabbatillah, S. 2019. Pola Asuh Orang Tua dalam Penggunaan Media Sosial Facebook pada Anak Sekolah Dasar. Sosial Horizon: Jurnal Pendidikan Sosial, 6 (1). 
15. Rahmawati, M. 2019. Tingkat Penggunaan Gawai dan Interaksi IbuAnak, serta Perkembangan SosialEmosional Anak PraSekolah. Bogor: Institut Pertanian Bogor.

16. Subhan, Firmansyah Adi. 2018. Hubungan Perilaku Penggunaan Gawai dengan Kualitas Tidur pada Mahasiswa Keperawatan Semester VI (Enam) di Universitas 'Aisyiyah Yogyakarta. Yogyakarta: Universitas Aisyiyah Yogyakarta.

17. Muflih, et al. 2015. Penggunaan Smartphone dan Interaksi Sosial pada Remaja di SMA Negeri 1 Kalasan Sleman Yogyakarta. Idea nursing journal.

18. Saifullah, M. 2017. Hubungan Penggunaan Gadget terhadap Pola Tidur pada Anak Sekolah di UPT SDN Gadingrejo II Pasuruan. Available at: http://repository.unair.ac.id/79

251/2/FKP.N.251- 18\%20Sai\%20h.pdf. [Accessed 9 Dec 2019]. 